Contemporary Social Science

Journal of the Academy of Social Sciences

ISSN: 2158-2041 (Print) 2158-205X (Online) Journal homepage: http://rsa.tandfonline.com/loi/rsoc21

\title{
Youth in the age of anxiety: the case of a southern European location
}

\section{Valerie Visanich}

To cite this article: Valerie Visanich (2017): Youth in the age of anxiety: the case of a southern European location, Contemporary Social Science, DOI: 10.1080/21582041.2017.1385829

To link to this article: http://dx.doi.org/10.1080/21582041.2017.1385829

曲 Published online: 13 Nov 2017.

Submit your article to this journal $\sqsubset$

View Crossmark data $\nearrow$ 


\title{
Youth in the age of anxiety: the case of a southern European location
}

\author{
Valerie Visanich \\ Department of Sociology, University of Malta, Msida, Malta
}

\begin{abstract}
This paper examines the sociological implications of personal anxiety for youth in tertiary education. The arguments brought forward are positioned broadly within a discourse on individualisation - on how youth today are devising their lives on their own free-will and experiencing anxiety due to self-reliance. Various socio-economic and cultural conditions have a direct impact on their degree of anxiety. This paper focuses on three of them - changes in the educational system, employment prospects and personal debts. This paper analyses increased anxiety in youth, outlined by various studies, and how it transcends in southern Europe. The data drawn on for this paper are taken from interviews conducted in Malta. The implications brought forward include the need for a more detailed exploration of the familial support network and its work in reducing anxiety. Youth experience a kind of 'institutional individualisation' - Their reflexive deliberations leading to angst are cushioned by their familial support network.
\end{abstract}

\author{
ARTICLE HISTORY \\ Received 3 July 2017 \\ Accepted 24 August 2017

\section{KEYWORDS} \\ Youth; agency; \\ individualisation; anxiety; \\ southern Europe; Malta
}

\section{Introduction}

In recent years, young people in Western societies are arguably having more autonomy in designing their own life and navigating their life trajectories in a highly individualised way, compared to their predecessors. Nevertheless, the increased self-reliance is also producing anxiety in taking responsibility for actions and failures. In liberal democracies today, in the so-called crisis of youth, within a risk and individualised society, is central to debates about youth. Even though most of these studies on the process of individualisation in the west have come to take centre stage in debates, its application in the life domain of youth in a southern European context is more or less absent in the social sciences. This article tackles this shortcoming.

This article assesses how the individualisation process transcends in the life experiences of young people in a location in the European south. Reference is made to studies and statistics on various southern European countries. The intention is to provide a contextual framework of structural conditions that influence the degree of anxiety amongst youth. The framework of this study can be applied to any other given location that is also in ambivalence between modernity and tradition. 
In particular, this paper draws data from one southern European country, the small island state of Malta, a location that is still relatively traditional due to its' somewhat strong Catholic morality and kinship ties, making it an ambivalent location (Mitchell, 2002). The Catholic Church has considerable political, social and cultural influence and a central role in the provision of non-state social welfare. Nevertheless recent reforms, such as the legislation of divorce and granting more LGBTIQ rights indicate a more liberal society (Briguglio, 2016).

The isle of Malta is far too small to be considered as a model of southern Europe. Far from generalising by using Malta as a case study, this paper provides insights on a location in southern Europe which shares common cultural particularities but disparate economic conditions - an example of this is economic development in the last three decades of the twentieth century. One pertinent distinction between youth in Malta and in other southern European countries is the fact that Maltese youth do not pay fees for their undergraduate studies.

The data drawn on for this paper are taken from in-depth interviews with young people who have had opportunities for tertiary education. This is to make sense of youth whose life chances included opportunities for tertiary education and who, presumably, have more bargaining power in designing their life on their own free-will. The point to such analysis is two-fold. First, my purpose is to contribute to the discussion on the reflexive deliberations of youth and their anxiety in contemporary society. This is supplemented by reference to individual biographies in Malta. Second, this article concludes by emphasising the importance of the extended family and its central role in the life of youth in southern Europe that cushions some of the consequences of their individualised life experiences. The very idea of 'institutional individualisation' in this article goes beyond the welfare-institutional order (Frericks, Höppner, \& Och, 2016) influencing youth. It refers to the support structures of youth within the southern European conditions, in particular those in Malta, and how such structures cushion the harsh effects of living a 'life of one's own'.

\section{Discourses on youth anxiety}

In recent years, discourse on anxiety in the so-called risk society has been prominent in social sciences on the situation of youth today (Beck, 1992; Giddens, 1991). However, anxiety amongst youth is not a contemporary phenomenon. In his book The Student in the Age of Anxiety, Ferdynand Zweig (1963) highlighted some of the constraints experienced by university students in the 1960s. He referred to the stress of university life and the anxiety youth experience in relations to work prospects and personal relations.

Youth, as a definitive autonomous stage of life, gained its prominence in the mid-twentieth century particularly with the emergence of the social category 'teenager' (Savage, 2008). However, the attribution of adolescence predates the Second World War. In order to describe the intermediate transitory phase between childhood and adulthood, Stanley Hall (1904), a psychologist, coined the term 'adolescence'. In his two-volume work, Hall (1904) presented a detailed account of this stage of life clearly defined by age, extending over the period of 14-24 years. During this life course of 'storm and stress', individuals experience biological development during puberty as well as socially constructed developments that typify this stage. In addition, Hall (1904) considered 
adolescents as being particularly influenced by their peers and the print media. To some degree, the risk behaviour is associated with identity exploration and the desire for new intense experiences in sensation seeking. He argued that this life stage needs to be lengthened and marked by specific rites of passage in order to provide young people with a refuge within the industrial society. Such refuge during times of anxiety is more than ever required especially in late modernity, in the individualised life domain.

Nevertheless in sociological literature, youth is not only studied in terms of anxiety but also as a time for increased exploration and self-focus. Jeffrey Arnett's conceptualisation of 'emerging adulthood' looks at youth as a liminal stage when individuals are enjoying not having full adult responsibilities. Young people free themselves from the normative expectations of childhood dependency and move into exploring the variety of possible life directions. For Arnett (2001) young people in their early twenties tend to be more committed to move out of the family home, establish stable relationships and choose their adult identity. However, typically young people do not regard themselves as adults but more as individuals making long-term commitments and decisions (Arnett, 2001).

\section{The individualisation process in the life domain of youth}

The process of individualisation refers to increased freedom of choice yet at the same time increased risks (Archer, 2000, 2003; Bauman, 1996; Beck, 1994; Beck \& Beck-Gernsheim, 2008[2002]; Giddens, 1991). Life biographies are said to be witnessing a threat in predictability and certainty when individuals are now the directors of their own life;

Individualisation liberates people from traditional roles and constraints in a number of ways ... women are cut loose from their 'status fate' of compulsory housework and support by a

husband ... . (Beck \& Beck-Gernsheim, 2008[2002], pp. 202-203)

Therefore the concept of individualisation is seen as contradictory - while it provides choice for individuals, nonetheless it produces anxiety and uncertainty. This need to be contextualised within socio-economic conditions of the laissez-faire ideology in late modernity in countries where neo-liberal policies are embraced and applied, by the removal of regulations and restrictions on trade (Bauman, 1998; Kamenetz, 2007; Sennett, 1998).

Within a global neo-liberal climate of competition and diminishing job security as well as increasing flexible short-term contract jobs, young people are anxious and find it a must to spend more time in education and equip themselves with a couple of degrees. Irrespective of the fact that Beck and Beck-Gernsheim (2008[2002]) deny the connection between individualisation and neo-liberalism, there is a close affinity between the two (McGuigan, 2010). In a neo-liberal society, the focus is on the individual rather than on society as a whole. By using the paradox of 'institutional individualism' Beck and Beck-Gernsheim (2008[2002]) and Zygmunt Bauman (2008) referred to the way legal norms of the welfare state are making individuals rather than groups dependent on institutions neo-liberal politics encourages individuals 'to devise individual solutions to socially generated problems and to do it individually, using their own skills and individually possessed assets' (Bauman, 2008, p. 4). Although short-term contracts may seem that they are promoting opportunistic bargaining, youth tend to suffer from both economic and psychological effects (Heery \& Salmon, 2000). In the name of individual 'sovereignty', neo-liberal mechanisms build an arena where individuals compete with one another in 
the fight for economic security. This Darwinian conflict is fuelled by threats of restructuring and fear of job loss. In effect, increase in involuntary job contracts in the Western society brought about an increased risk of unemployment and reduced earnings (Heery \& Salmon, 2000). Consequentially, this results in anxiety amongst youth.

\section{Education, employment and debt}

At the end of the twentieth century, more attention was paid to the preparation of youth and their eventual entry into the labour market (Roberts, 1995). Up until the 1980s, having no academic qualifications did not hinder finding work in places like in Britain - The labour market absorbed virtually all persons and opportunities for the unqualified and unskilled were easily available (Bynner \& Côté, 2008).

This situation shifted with changes in the educational system and credentials - 'youth have had little choice but to seek post-secondary educational credentials in the hope of gaining an advantage in access to better-paying jobs' (Bynner \& Côté, 2008, p. 260). As a result, young people have to finance their own education with the consequence of entering into significant debts before joining the workforce (Kamenetz, 2007). Moreover, the workforce is much more 'flexible' than ever before. The decline in career-long employment is replaced with contingent contracts and a mobile workforce. Changes in the external labour market and national systems of employment regulation are causing greater insecurity amongst employees (Heery \& Salmon, 2000).

Although short-term contracts may seem that they are promoting opportunistic bargaining for employees, workers tend to suffer both from economic and psychological effects (Heery \& Salmon, 2000). The replacement of stable jobs with flexible labour mainly in the form of fixed contracts is the result of neo-liberal consumer choice (Bauman, 1998).

\section{The southern European context}

Beck (1992) argues that processes of reflexive modernisation 'tend to dissolve' traditional conditions of industrial society. Individuals are increasingly released from these conditions of 'conscience collective' such as class, gender and family relations (Beck, 1992, p. 87). However, the situation in southern Europe is not as straightforward as explained by Beck.

Southern European countries such as Cyprus, Spain, Portugal, Greece, Italy and Malta, have certain characteristics which distinguish them - not only their geographic proximity, but also their common historical and cultural legacies (Gal, 2010). Such common cultural characteristics include the influence of religion (in particular Catholicism) in all aspects of social life as well as the central role of the family and the presence of 'familism' (family solidarity and dependency).

The importance given to kinship networks changes the understanding of the functioning of the welfare state. Gøsta Esping-Andersen (1990) was one of the first scholars to speak about the particularities of countries like Spain, Italy and Greece in the conservative welfare regime, as opposed to countries like Germany, Austria and the Netherlands.

José Pereirinha (1997) maintained that Esping-Andersen's (1990) model on the decommodification of welfare services contains two limitations when applied to southern European countries. Primarily, such model excludes the informal labour market which has a significant presence in the south. Also, it ignores mechanisms of social solidarity and 
the informal institutions, such as the Catholic Church and its various organisations that work to combat poverty and social exclusion in society. Thus, Pereirinha (1997) supported the argument that studies on the welfare state cannot rely exclusively on the state and the market but need to address the role of the civil society, families and the voluntary sector.

Malta's welfare model is considered as a hybrid model which does not fit neatly in one particular model of welfare outlined by Esping-Andersen (Briguglio \& Bugeja, 2011). Unlike other western countries moving further away from the welfare state, towards a more neoliberal market oriented model, social welfare provisions in Malta are not yet an endangered or contested concept (Briguglio, Bugeja, \& Vella, 2016).

Albeit these common cultural conditions, it is pertinent to note out disparate economic conditions of such countries. For example, Malta has not undergone economic crisis like Greece, Italy, Spain and Cyprus. On contrary, GDP growth rate in Malta from 2000 until 2016 averaged at $0.80 \%$ reaching an all-time high of $4.40 \%$ in the first quarter of 2014 (trading economics, 2017).

\section{The case of Malta}

Malta's specific characteristics, not only as a southern European country, but also as a small island state should be taken into consideration here. Similar to other small states, Malta's peculiarities include its openness to international trade and high dependence on imports due to their small economic size (Briguglio, 2014). The vulnerability of Malta to external events is in its 'suddenness of impact, in the intensity of effect and in the rapid speed of penetration'. (Baldacchino, 1998, p. 225).

Malta's economic development reached a surge in the last three decades of the twentieth century, especially with the development of the welfare state, the national health services and the implementation of subsidised housing. It is also worth noting Malta's social wage, comprising of universal benefits like free healthcare and free education. Maltese students at the University of Malta do not pay fees for their undergraduate studies but are given universal maintenance grants as well as receive a stipend during their course of studies. Such local peculiarity, therefore, tends to encourage young people into post-compulsory education.

However, this initiative is not completely reaching its objectives because the number of Maltese youth entering university (26\%) is lower than the EU average (European Commission, 2013). The EU targets are for these figures to climb to $30 \%$ by 2020 . Furthermore, the early school leaving rate of Maltese students is the second highest rate in the EU at $20.8 \%$ (European Commission, 2013).

The situation of youth unemployment is also less problematic in Malta (6.9\%) when compared to the EU average rate of $18.6 \%$ and other southern European countries like Greece (50.4\%), Spain (43.9\%) and Italy (36.9\%) (Eurostat, 2015). The European Economic Forecast (2016) reports that Malta's continued economic growth and job creation are accountable for the low rate of unemployment. Such economic conditions have a significant influence on the degree of anxiety experienced by youth in Malta because it smoothens the transition from education to work.

Apart from economic conditions, it is worth noting recent changes in Malta indicating a more liberal society, which can be interpreted as the weakening of the Church's influence (Briguglio, 2016). Civil society organisations have been pertinent in a number of 
campaigns promoting civil activism, such as the 'Yes' movement for the legislation of divorce. This movement emerged victorious in the 2011 referendum and this led to the legislation of divorce in Malta in October 2011. Another recent move towards a liberal society was the legalisation of same-sex unions, following the enactment of Civil Union Act in 2014. It has been argued that in the space of six year, the institutions of marriage was challenged in Malta, not because of marital breakdown, but due to the rejection of traditional codes of sexual behaviour, especially by youth (Abela, 2013).

Furthermore, in recent years there has been an increasing diversity in family life in Malta, partly due to immigration flows contributing to growing numbers of intercultural marriages - thus the traditional family is no longer the only family form (Abela, 2016). Young people in Malta are increasingly identifying themselves with some aspects of global youth culture, such as consumerism and social media (Cassar, 2016).

\section{The study}

The significance of this article is that it questions the extent of personal anxiety in the life domain of youth in tertiary education. The research uses a qualitative approach, extending over a period of approximately 24 months, between 2010 and 2012, employing 12 indepth interviews with Maltese youth. The aim of drawing from this research is not to generalise on southern European youth in general, but to give insights on the life experiences of a social group of youth and their experienced anxieties.

Young participants were deliberately selected for their specific particularities of being in tertiary education. The selection of participants also included taking into consideration variables like age and gender. A balanced amount of males and females participants were chosen, between the ages of 21 and 26 years. A Purposive sample was used to select participants. My personal network was used to handpick participants that fit this criterion through sound judgement. After contacting them by phone and explaining my research, participants agreed to meet and were interviewed about their lived experiences. All participants whose interviews I am drawing here were white, heterosexuals and living in Malta. They all had post-compulsory education, therefore their interpretations are in no means a normalised experience for all young people of the same age group. Interviews were conducted in person.

All ethical procedures have been followed and participants recruited were informed of their rights to view transcripts, their right to withdrawal and of having their names changed to safeguard their anonymity.

The process of transcription was followed by a thematic analysis, which pinpointed, examined and recorded patterns in the data. Various valid themes emerged from the data analysis process, including on participants' life chances and future plans of this social group of youth. Such analysis may be useful and dealt with elsewhere. However, this article focuses on three themes centred on anxiety amongst youth - on the changes in the educational system, employment prospects and rise in personal debts.

\section{Findings: uncertainties and reflexive decisions}

High unemployment and austerity measures in southern European countries give rise to increased social disintegration and anxiety. Greece is an example of this in which 'no 
other European state has undergone such pain in the last fifty years or more' (Featherstone, 2014). The economic and political crisis in Greece is producing self-suffering (Tsekeris, Kaberis, \& Pinguli, 2015). Consequentially, the worsened socio-economic conditions are pervasive in the everyday life of individuals (Economou, Madianos, Peppou, Patelakis, \& Stefanis, 2013).

However, for participants in this study, their primary causal factor for anxiety was the experience of uncertainty when choosing their career paths rather than fear of unemployment as in other southern European countries. One explanation for this is the high employment rate of tertiary graduates in Malta which stands at $93 \%$ and amongst the highest in the EU (European Commission, 2013). Participants emphasised their deliberate reflexivity in choosing what they want to do in their life, where to study and which career to pursue. They were also aware that the process that offers such choices also creates risks and consequentially anxiety. In a similar manner to what Beck and Beck-Gernsheim (2008 [2002]) argued, 'your own life - your own failure', social problems become linked to psychological dispositions like guilt and anxiety. In line with Bynner and Côté (2008), participants felt pressured by the educational system to obtain higher educational qualifications with the hope of gaining an advantage in access to better-paying jobs.

Jane, a 24-year-old participant, said that she felt the need to increase her marketability by studying for a Master's degree. Equally worried about the lack of predictability, Maria, a 21-year-old participant, maintained that 'I am really anxious about my future. The fact that I won't have things planned out really scares me.' Shouldering individual responsibility made her anxious about the future.

The increased importance to qualifications, especially a university degree, is now a universal goal for young people with similar life chances as the research participants. Participants felt that a university degree was part of their trajectory into adulthood even though they were unsure what to do in their life. For instance, Lara, a 23-year-old student emphasised this;

I am studying but I don't know for what. It was just a normal process that I had entered university after obtaining my Advanced Levels. But still, I don't know what I want to do in life and which job to go for.

Jane maintained that she had more alternatives today compared to her parent generation. Her ambition was to be a psychologist. Regardless of Jane's perceived advantageous position in having the ability to devise her own life-plan, she also felt anxious about her future and in a liminal stage as an emerging adult. In a powerful discourse about the shift in females' life chances, Jane compared her situation with her grandmother's. She said that she has more things to think about, more stress to deal with and more uncertainty about what to do.

Life was simpler. Although I think today women have more opportunities but I think life was simpler. Women had fewer anxieties. They only thought about marriage. So advancement has also brought about negative consequences like anxiety. A woman used to think about marriage and childcare whereas today she needs to balance the family with a career. Sometimes when I'm very anxious, by the way I'm a feminist, but sometimes I say it was better when we were simpler.

Jane felt anxious with no certainty or permanence in her chosen career path. Her 'do-ityourself biography', albeit exciting, is contradictory, especially in line with the changes 
in the educational system and credentials. Her decision to further her studies had also a significant impact on her free and leisure time. The concept of work-life balance and the support structures in place such as by family members are important considerations when studying leisure patterns amongst youth (Clark \& Cassar, 2013).

It can be argued that liberating conditions from traditional stereotypical roles created a contradictory situation. In particular, young female participants maintained that they are faced with greater individual choice but they also have to shoulder new responsibilities and deal with more anxiety. Despite the progress made toward the equalisation of sexes in Malta, as a southern European location, young females are not completely released from traditional gender roles. Besides their reflexive deliberations, most female participants spoke about the need to juggle work and family in the future. Albeit the rapid increase in the rate of women working, there is still a considerable division of gender roles in the Maltese family (Abela, 2016). It is not the case, as the Beck and Beck-Gernsheim (2008[2002]) asserted, that 'in education young women increasingly face the same demands and opportunities as men and not least for this reason they develop increasingly similar expectations and demands for their career' (Beck \& BeckGernsheim, 2008[2002], p. 66).

\section{Cushioning anxiety}

The socio-economic and cultural conditions of the research location need to be taken into consideration when analysing the debt situation of youth. The stress and anxiety of young participants are, in part, being cushioned by a number of socio-economic and cultural factors.

First, none of the research participants took up loans to finance their undergraduate degrees because of the free tertiary educational system in Malta.

Second, financial difficulty and debts linked to unemployment is one causal factor for anxiety amongst youth. The low rate of youth unemployment, as already explained, is cushioning financial anxiety. This makes the transition from school to work a smooth move towards financial autonomy.

Third, participants emphasised the centrality of the community, family-oriented principles and family obligations in their everyday life. Robert Putnam (1995) emphasised the important of a 'community' with a close network of social relations, in what he refers to as social capital 'features of social organisation such as networks, norms, and social trust that facilitate coordination and cooperation for mutual benefit' (Putnam, 1995, p. 67). The concept is beneficial because of three elements - confidence, reciprocity and networks (Putnam, 1995). These tie in with the need to cultivate connections in Malta through the close network of social relations (Baldacchino, 2013). Moreover, such networks and the family cushions youth's transition into adulthood. This needs further elaboration to make sense of participants' responses.

\section{High intensity of kinship networks}

The significance of the kinship network in the southern region is different to the more central and northern European countries - what Reher (1998) refers to as the 'weak' family link of the northern European nuclear setting compared to the 'strong' family ties 
of the Mediterranean region. An example of this is the difference in family obligation in care for intergenerational relations and the way the family organises support for its most vulnerable members (Cliquet, 2003; Viazzo, 2010). Similarly in Malta, the extended family occupies a central role in the provision of support for all members - an example of this is in the way the extended family organises innovative rotating care patterns to accommodate vulnerable, especially elderly, family members (Innes, Abela, \& Scerri, 2011).

It has been argued that societies with traditional strong family ties, characterised by the extended family setting, are more willing to accommodate for the needs of vulnerable members in the family (Cliquet, 2003; Reher, 1998). These usually include dependent members like young people who are financially dependent on their parents. In Greece, for instance, young people living in the climate of high unemployment, rely on their parents for financial support - a situation that can change, according to Greek youth, through solidarity, cooperation and volunteerism (Tsekeris, Pinguli, \& Georga, 2015).

Parents are also willing to provide financial support to buy various consumer goods. Financial anxiety is also fuelled by the culture of consumerism (Kamenetz, 2007). Youth are especially seduced by the all-embracing Western consumer culture that incorporates even disaffection and rebellion into capitalism itself - what Jim McGuigan (2009) refers to as 'Cool Capitalism'. One participant enthusiastically referred to the culture of conspicuous consumption, yet she spoke about her limited budget since she is still financially dependent on her parents. Most of the respondents embraced the mantra of 'never spend beyond my budget'. Even though most participants considered themselves easily seduced by consumer goods, they proudly declared that they kept their feet firm on the ground and never stretched out for something that they cannot afford. David summarised this by saying 'I am not ready to buy stuff just to be like others and end up with loans.' Such characterisation has affinities with the principle to 'save up for a rainy day' as one of the traditional fundamental values of the Maltese society.

Mark, in particular, was trained during childhood to be financially responsible. He declared that he doesn't have any financial problem;

I don't really have a problem. My mother ... because of the fact that she brought us up in the absence of my father, always taught us to save money ... I spent some time working part-time and managed to save up some money so if I want to buy a car I won't have to borrow or rely on anyone because I have my money.

Even though participants said they would not spend beyond their means, they referred to need to take up bank loans in the near future, especially when buying their own property. It is typical for young people in Malta to buy a property rather than rent it. It is often the case therefore, that the financial situation of young people becomes dire when they take their first home loan; usually after starting working full-time. In view of this, most participants were aware that they don't afford to fully enter independent living before having a full-time job.

Nevertheless, participants referred to the way the close-knit family environment in Malta is at times sheltering youth from the preoccupations of future financial debts. Despite the fact that most of the time parents cannot afford to financially support their children into buying a property, they tend to find ways to ease the financial burden and reduce anxiety. Jane referred to a typical solution that some parents are adopting; 
We thought of redesigning again my mother's house cause my brother is an architect and we were planning to reconstruct the house so I will have the upper floor and he will have the lower floor. But that is a future plan.

\section{Leaving parental home}

Hedonistic consumerism coupled with student loans to finance higher education, credit card debt and the high cost of housing are resulting in a gloomy life situation for most Western young people (Kamenetz, 2007). It comes to no surprise that young people are leaving their parental home at a later age or even return back living with their parents after college due to financial difficulty - a trend which gave youth today the name of a boomerang generation.

Youth's financial situation is one of the main reasons why they are delaying leaving parental home according to the 'Youth in Europe' survey (Eurostat, 2009). This is a case in countries like Italy (Ferrera, 1996; Reher, 1998; Rosina \& Fraboni, 2004). Culturally, Maltese youth share similar tendencies to other southern Europeans. The average age of leaving parental home in Malta is 30.1 years; one of the highest in the EU28 (Eurostat, 2013). Empirical evidence showed that this delay in Malta can be explained in three ways, due to financial, cultural and geographical conditions.

First, the lack of financial stability, mainly due to extending years in training is delaying having a full-time job and transitioning into independent living. This is resulting in lengthening the years of financial dependence on parents.

Second, the high intensity of kinship network, interlaced with a Catholic mentality, reinforces the tendency of moving out of parental home upon marriage. Southern European young adults give importance to the attitudes and values of their parents, particularly when leaving parental home and making their family formation choices (Di Guilio \& Rosina, 2007; Esping-Andersen, 1990; Ferrera, 1996). Compared to most northern European countries that witnessed an increase in youth's formation of informal unions, for southern European youth leaving the parental household usually coincides with marriage (Reher, 1998; Schröder, 2008). Di Guilio and Rosina (2007) refer to the way Italian parents are deeply involved emotionally in the lives and decisions of their adult children, including in their choices on marriage and cohabitation - it is also a case that 'children ... avoid choices which openly clash with the values of parents' (Rosina \& Fraboni, 2004, p. 162).

Malta's high institutionalisation of marriage plays a crucial role in youth's decision to lengthening their years living at their parental home. All participants were still living with their parents during the time of interview. This was not solely a financial decision for them, but a cultural one. Most participants felt obliged to respect their parents' values and leave home upon marriage. Two respondents maintained that their parents would not be pleased if they decided to live on their own before getting married. Elena said that her mother warns her that she will not accept her back home if she decides to leave; 'my mother ... she always says that once we leave, she won't accept us back home.'

Third, due to the smallness of the Maltese islands the scope of living on campus does not make sense because of the short distances. David spoke about this peculiarity;

In Malta, due to the short distances, even if you opt to leave, your bond with the extended family remain strong and if something happen to you, you can easily go back home. 
As a general rule, most participants in this research had no interest to live on their own but hoped to remain in partial dependence as long as possible. They felt free from normative expectations of childhood dependency and in a stage of exploring the variety of possible life directions. In line with Arnett (2001), they were in a stage of emerging adults, choosing their adult identity by making long-term commitments and decisions. Participants admitted that they were living comfortably at their parental home, being financially and emotionally supported. Anthony's reply is an exemplary reply of their unwillingness to move out;

I still live with my parents and I will leave when getting married. The reason is that my parents never restricted me in anyway. If I want to go back home at five in the morning, they don't restrict me not to. I don't see why I should leave. Water and electricity bills are sent to my father and I am happy as it is.

\section{Discussions}

\section{Institutional individualisation and anxiety}

From this research, it was possible to discern a number of patterns in the ways participants dealt with their anxiety. This article referred to the role of the family and support network, in a time of increased emphasis on self-reliance. Recent literature on the life experiences of young people, in the Anglo-American context, refers to an individualisation boost (Beck \& Beck-Gernsheim, 2008[2002]). Notwithstanding the credibility of Beck and Beck-Gernsheim's argument, this study has shown that this process is not consistent with the cultural variables in a southern European context. Anxiety amongst youth in Malta is cushioned by the family support network - this supports youth both financially and emotionally and as a result it reduces anxiety. Furthermore, the very fact that Malta did not undergo an economic crisis, just like other southern European countries, as well as the low rate of youth unemployment, are also attributable factors towards the degree of anxiety experienced.

There is a kind of 'institutional individualisation' in the life domain of youth in Malta - a balanced view between contextual support structures and reflexive deliberations. This concept builds on the study on institutional individualisation in the welfare-institutional order (Frericks et al., 2016) and looks into youth's informal support network in southern Europe and how this is cushioning anxiety. Young people in southern European countries have more freedom in devising their own life, yet the family support structure is influential in their decisions. Similar to the concept of 'structured individualisation' (Nagel \& Wallace, 1997; Furlong \& Cartmel, [1997]2007), a balanced view of the structure-agency relation is needed when examining the life experiences of youth.

This paper suggests the need for a more nuanced exploration of the changes in the life experiences of young people in other locations in southern Europe, to build a better understanding of the complex relationship between structural constraints and individual agency. The framework set out here can be broadened and applied to explore other instances where youth's choices are continuously influenced by other contextual factors and in other locations. It would also be useful to explore the application of individualisation to young people with diverse life conditions and chances to assess how the process of individualisation transcends to other social groups who may not have opportunities for tertiary education. 


\section{Conclusion}

Studies on the state of anxiety in youth have been central in youth studies especially in Sociology and Psychology. The significance of this article is that it positions such discussion within the discourse on individualisation to provide a credible explanation of the situation of the life situation of youth today. It focuses on how this transcends in southern Europe, in the life domain of youth in tertiary education by exploring their degree of reflexive deliberations as well as anxiety. The peculiar socio-economic and cultural characteristics of the South were taken into consideration here. This paper focuses on three of such peculiarities - in the educational system, employment prospects and personal debts.

A number of implications were brought forward in this discussion. The familial support network plays a crucial role in reducing anxiety, both through financial and emotional support. Youth experience a kind of 'institutional individualisation' in which their reflexive deliberations, leading to anxiety, are cushioned by their family especially during the lengthening years of living at their parental home.

\section{Acknowledgements}

The author would like to thank Jim McGuigan for his helpful support throughout the writing of this study.

\section{Disclosure statement}

No potential conflict of interest was reported by the author.

\section{Notes on the contributor}

Dr Valerie Visanich is a lecturer at the Department of Sociology, University of Malta. Her main fields of interest are sociology of culture and art and youth studies. She is chair (2017-2019) of the European Sociological Association, Research Network Sociology of Art (RN2). She is also the co-founder and chairperson of the Malta Sociological Association.

\section{References}

Abela, A. (2013). Divorce in Malta. In R. E. Emery (Ed.), Cultural sociology of divorce: An Encyclopaedia (Vol. 2, pp. 748-752). Thousand Oaks, CA: Sage.

Abela, A. (2016). Family life. In M. Briguglio \& M. Brown (Eds.), Sociology of the Maltese Islands (pp. 1846). Luqa: Miller.

Archer, M. (2000). Being human: The problem of agency. Cambridge: Cambridge University Press.

Archer, M. (2003). Structure, agency, and the internal conversation. Cambridge: Cambridge University Press.

Arnett, J. (2001). Adolescence and emerging adulthood: A cultural approach. Upper Saddle River, NJ: Pearson Prentice Hall.

Baldacchino, G. (1998). Far better to serve in heaven than to reign in hell: Malta's logic of relating to the European Union. In G. Baldacchino \& R. Greenwood (Eds.), Competing strategies of economic development from small islands (pp. 213-238). Charlottetown: Institute of Island Studies, University of Prince Edward Island.

Baldacchino, G. (2013). Social class in Malta: Still our daily bread. Centre for Labour Studies, Biennial Report 2011-2013, University of Malta. Retrieved from https://www.um.edu.mt/_data/assets/ pdf_file/0010/191197/biennial_doc_2012.pdf 
Bauman, Z. (1996). From pilgrim to tourist - or a short history of identity. In H. Stuart \& P. Du Gay (Eds.), Questions of cultural identity (pp. 18-26). London: Sage.

Bauman, Z. (1998). Globalization - The human consequences. Cambridge: Polity Press.

Bauman, Z. (2008). The absence of society. In Joseph Rowntree Foundation, The social evils series. York: Joseph Rowntree Foundation.

Beck, U., \& Beck-Gernsheim, E. (2008[2002]). Individualization. London: Sage.

Beck, U. (1992). Risk society: Towards a new modernity. London: Sage.

Beck, U. (1994). The reinvention of politics: Towards a theory of reflexive modernization. In U. Beck, A. Giddens, \& S. Lash, (Eds.), Reflexive modernization. Politics, tradition and aesthetics in the modern social order (pp. 1-55). Cambridge: Polity.

Briguglio, L. (2014). A revised vulnerability and resilience framework. Retrieved from https://www.um. edu.mt/_data/... S Small_states_Competitiveness_and_resilience.pdf

Briguglio, M. (2016). Political parties and social movements. In M. Briguglio \& M. Brown (Eds.), Sociology of the Maltese Islands (pp. 324-337). Luqa: Miller.

Briguglio, M., \& Bugeja, I. (2011). Exploring Malta's welfare model. Bank of Valletta Review, 43, 12-27.

Briguglio, M., Bugeja, I., \& Vella, M. G. (2016). Social policy, poverty and social exclusion. In M. Briguglio \& M. Brown (Eds.), Sociology of the Maltese Islands (pp. 374-390). Luqa: Miller.

Bynner, J., \& Côté, J. (2008). Changes in the transition to adulthood in the UK and Canada: The role of structure and agency in emerging adulthood. Journal of Youth Studies, 11(3), 251-268.

Cassar, J. (2016). Youth. In M. Briguglio \& M. Brown (Eds.), Sociology of the Maltese Islands (pp. 69-82). Luqa: Miller.

Clark, M., \& Cassar, J. (2013). Leisure trends among young people in Malta. Office of the Commissioner for Children and Agenzija Zghazagh, Malta. Retrieved from https://www.academia.edu/29766207/ Clark_M._and_Cassar_J._2013_._Leisure_Trends_Among_Young_People_In_Malta._Malta_ Office_of_the_Commissioner_for_Children_and_AC4A1enzija_C5BBgC4A7aC5BCagC4A7

Cliquet, R. (2003). Major trends affecting families. New York, NY: United Nations.

Di Guilio, P., \& Rosina, A. (2007). Intergenerational family ties and the diffusion of cohabitation in Italy. Demographic Research, 16(14), 441-468.

Economou, M., Madianos, M., Peppou, L. E., Patelakis, A., \& Stefanis, C. N. (2013). Major depression in the era of economic crisis: A replication of a cross-sectional study across Greece. Journal of Affective Disorders, 145(3), 308-314.

Esping-Andersen, G. (1990). The three worlds of welfare capitalism. Princeton, NJ: Princeton University Press.

European Commission. (2013). Education and training monitor 2013. Retrieved from http://ec.europa. eu/dgs/education_culture/repository/education/library/publications/monitor13_en.pdf

European Commission. (2016). European economic forecast winter 2016. Retrieved from http://ec. europa.eu/economy_finance/publications/eeip/pdf/ip020_en.pdf

Eurostat. (2009). Youth in Europe, A statistics portrait. European Commission, Luxembourg: Publications Office of the European Union.

Eurostat. (2013). What it means to be young in the European Union today. Retrieved from http://ec. europa.eu/eurostat/documents/2995521/6783798/1-16042015-AP-EN.pdf/5d120b02-c8df-4181$9 \mathrm{~b} 27-2 \mathrm{fe} 9 \mathrm{ca3c}$ c b6b

Eurostat. (2015). Euro area unemployed at 10.1\%. May 2016. Retrieved from http://ec.europa.eu/ eurostat/documents/2995521/7545626/3-01072016-AP-EN.pdf/4281f757-75ef-4463-a15cca9f968b8513

Featherstone, K. (2014). The political challenges of institutional reform in Greece. Policy Network. Retrieved on 23 November 2016. http://www.policy-network.net/pno_detail.aspx?ID= 4578\&title=The-political-challenges-of-institutional-reform-in-Greece

Ferrera, M. (1996). The 'southern model' of welfare in social Europe. Journal of European Social Policy, 6(1), 17-37.

Frericks, P., Höppner, J., \& Och, R. (2016). Institutional individualisation? The family in European social security institutions. Journal of Social Policy, 45(4), 747-764.

Furlong, A., \& Cartmel, F. ([1997]2007). Young people and social change. Berkshire: Open University. 
Gal, J. (2010). Is there an extended family Mediterranean welfare states? Journal of European Social Policy, 20(4), 283-300.

Giddens, A. (1991). Modernity and self-identity. Self and society in the late modern age. Cambridge: Polity.

Hall, S. G. (1904). Adolescence: Its psychology and its relations to physiology, anthropology, sociology, Sex, crime, religion and education. New York, NY: D Appleton and Company.

Heery, E., \& Salmon, J. (Eds.). (2000). The insecure workforce. London: Routledge.

Innes, A., Abela, S., \& Scerri, C. (2011). The organisation of dementia care by families in Malta: The experiences of family caregivers. Dementia (Basel, Switzerland), 10, 165-184.

Kamenetz, A. (2007). Generation debt. New York, NY: Riverhead Books.

McGuigan, J. (2009). Cool capitalism. London: Pluto Press.

McGuigan, J. (2010). Cultural analysis. London: Sage.

Mitchell, J. (2002). Ambivalent Europeans, ritual, memory and the public sphere in Malta. London: Routledge.

Nagel, U., \& Wallace, C. (1997). Participation and identification in risk societies: European perspectives. In J. Bynner, L. Chisholm, \& A. Furlong (Eds.), Youth, citizenship and social change in a European context (pp. 42-55). Aldershot: Avebury.

Pereirinha, J. (1997). Welfare states and anti-poverty regimes: The case of Portugal. In M. Rhodes (Ed.), Southern European welfare states, between crisis and reform (pp. 198-239). London: Frank Cass.

Putnam, R. D. (1995). Bowling alone: America's declining social capital. Journal of Democracy, 6(1), 65-78.

Reher, D. S. (1998). Family ties in Western Europe: Persistent contrast. Population and Development Review, 24(2), 203-234.

Roberts, K. (1995). Youth and employment in modern Britain. Oxford: Oxford University Press.

Rosina, A., \& Fraboni, R. (2004). Is marriage losing its centrality in Italy. Demographic Research, 11(6), $149-172$.

Savage, J. (2008). Teenage: The creation of youth 1875-1945. London: Pimlico.

Schröder, C. (2008). The influence of parents on cohabitation in Italy: Insights from two regional contexts. Demographic Research, 19(48), 1693-1726.

Sennett, J. (1998). The corrosion of character. The personal consequences of work in the new capitalism. New York: W.W. Norton.

Trading Economics. (2017). Malta GDP growth rate. Retrieved from http://www.tradingeconomics. com/malta/gdp-growth

Tsekeris, C., Kaberis, N., \& Pinguli, M. (2015). The Self in crisis: The experience of personal and social suffering in contemporary Greece, GreeSE Paper No.92, Hellenic Observatory Papers on Greece and Southeast Europe, London School of Economics: London.

Tsekeris, C., Pinguli, M., \& Georga, E. (2015). Young people's perception of economic crisis in contemporary Greece: Crisis observatory, A social psychological pilot study. Hellenic Foundation for European and Social Policy, 19.

Viazzo, P. P. (2010). Family, kinship and welfare provision in Europe, past and present: Commonalities and divergences. Continuity and Change, 25(1), 137-159.

Zweig, F. (1963). The student in the age of anxiety. New York, NY: Free Press of Glencoe. 